\title{
BELGRADE AS SUBJECT OF MUSICAL COMPOSITIONS
}

\author{
Miloš Veli mirović (Charlottesville, Va.)
}

It is not unusual in the history of music to encounter compositions which refer to specific persons or to specific locales within which some sort of action is taking place, while the music 'describes' events. This type of occurence is, of course, most easily observed in operas although other types of compositions can also be found with similar 'placement' of an event or action. Operas on historical and pseudo-historical subjects were composed by dozens-of-dozens in the $18^{\text {th }}$ century, especially, and the history served basically as an 'excuse' for the presentation of a more of less contemporary story in a more 'respectable' surrounding; or - as seems to have been the case in some instances - the placement in a relatively exotic geographical location may have added some special attraction to the public, particularly if that area might be in the recent news.

The cities and regions of Yugoslavia have had an extremely varied and rich history and there is no need for a recounting of their past. Yugoslav artists have been inspired by many an event for new artistic creations in which such significant happenings have served as subjects. We are interested, however, in examining the impact on other European artists, particularly composers, in dealing with one subject: the city of Belgrade as the background for a story to be depicted in a musical composition.

The earliest reference to Belgrade as the locale of an action in a musical composition appears to have taken place in 1784 , to judge from the title for a ballet, named "L'assedio di Belgrado, fatto da Maometto II, soccorso e liberato da Giovanni Unniade governatore dell' Ungheria" with music by Antonio Bisoni - 'detto il Rossetto'. This and another ballet were performed together with an opera - 'Aspard' - composed by Francesco Bianchi on a libretto by Gaetano Sertor, staged during the carneval period in Rome, in the Teatro delle Dame. ${ }^{1}$

1 Oscar G. T. Sonneck, Catalogue of Opera Librettos' Printed before 1800 , I (Washington, 1914), p. 174, listed under the title Aspard, where the date 
The only information about the ballet appears at the end of the libretto of this opera and at the time of this writing it seems that no trace of the score of this ballet has been found. In fact, the composer Bisoni is also almost totally unknown. ${ }^{2}$ All that can be deduced with some degree of certainty is that whoever offered the subject to the composer for this ballet, must have known that in 1456 Belgrade was besieged by Turkish forces of Mohamed II, the conqueror of Constantinople in 1453, and that Janos Hunyadi, a distinguished Hungarian nobleman and regent, indeed succeeded in repelling the Turkish forces from conquering that strategic fortress at the confluence of the rivers Sava and Danube. ${ }^{3}$ One wonders what promted the selection of Belgrade in that year as the locale for an action, and no immediate reason can be detected, except that it was a city on the border of Turkey and Austria, in 1784 in Turkish hands for more than two centuries, although in the period of ca. 1719-1739 the Austrians had the city in their domain. ${ }^{4}$

As the political situation grew more tense in subsequent years, the period of 1788-1791 did lead to a war, another attack and siege of Belgrade and a rather short-lived Austrian domination of Belgrade from October 1789 to 1791 when the Turks took over again. ${ }^{5}$ This war and the presence of Belgrade in much of the news of the period has contributed to at least three musical compositions dealing with Belgrade. And the first of these was composed by no less a composer than Mozart.

Mozart's interest in this war, according to O. E. Deutsch, is attested by the composition of two songs (K. 539 and K. 552) and by a country

and place are given in addition to listing the two ballets, of which the second is one that is of interest at this point. I have personally examined the copy of the libretto in the Library of Congress in Washington, and Sonneck has published the full text. There is no other information about this piece; the annotation about the ballets and their titles appear at the very end of the libretto.

2 F.-J. Fétis, Biographie universelle des musiciens...., I (Paris, 1869), p. 429. lists »Bisoni, Antoine« and »Bissoni, A.«. The first presumably was a musician in Lugo in the 1780's and the second (with two 'ss') is listed as a 'bolognese' composer from the 'beginning' of the 18th c. Eitner's Quellenlexikon is the only other significant reference work to list Bisoni, who remains unlisted in more recent reference works.

3 The only account of this event in the English language in the modern scholarly literature seems to be by $R$. N. Bain, »The Siege of Belgrade by Muhammad II, July 1-23, 1456, " in The English Historical Review, VII (1892), 232-252; among the recent studies very detailed is the description of the siege in Jovanka Kalić-Mijušković's Beograd $u$ srednjem veku (Beograd, 1967), 127-161, of which a substantial part is restated in the first of the three-volume history of Belgrade - Istorija Beograda, I (Beograd, 1974). $189-217$.

${ }_{4}^{4}$ Cf. chapter xi in Istorija Beograda, I, pp. 521-584; the Austrian conquest of Belgrade of 1717 did lead to the German song about Prince Eugen of Savoy, which is well-known and described by Stana Djurić-Klajn in Historijski razvoj muzičke kulture u Jugoslaviji (Zagreb, 1962), p. 567.

${ }_{5}$ Cf. Istorija Beograda, I, pp. 724-735. 
dance (K. 535) entitled "La Bataille" or "The Siege of Belgrade". 6 The crucial document seems to be an advertisement in the Wiener Zeitung, of 19 March 1788, in which is announced the availability of -

New Battle-Song of a German soldier, by Herr Mozart, Kapellmeister in actual service of His Majesty the Emperor.

"Ich möchte wohl der Kaiser seyn", with all the parts, $1 \mathrm{fl}$. ditto in pianoforte score, - - "Die Belagerung Belgrads", with all the parts, $1 \mathrm{fl}$. ditto in pianoforte score, $12 \mathrm{kr}$. To be had at Lausch's music establishment...

Additional confirmation appears in another advertisement that a set of six country dances were published by Artaria, according to an announcement in Wiener Zeitung of January 17, 1789, and the set contained the work K. 535 as "La Bataille" and the same work was republished in February 1790 in Speyer under the same title. ${ }^{7}$ Otto E. Deutsch, also points out that in 1788 Mozart's name appeared in two lists of subscribers to new publications, ${ }^{8}$ one of which was Anton Stein's "Österreichische und türkische Kriegslieder" and this being a collection of war-songs it is thus presumed that Mozart did try to follow the stories which circulated in connection with the planned and impending activities of the Austrian army. The fact that in 1788 there was no direct confrontation of Austrians and Turks at Belgrade in no way diminishes the possibility that Mozart may have been led to believe that there was going to be some action as it might have been rumored at the time. Being keenly interested, no doubt, in keeping up with events, Mozart wrote a work which is but a 'pièce d'occasion'. What is a bit puzzling is the date of the autograph as listed in the last edition of Köchel's catalog, ${ }^{9}$ namely " 23 . Januar 1788" - which is apparently before the outbreak of hostilities, though the situation at the border may have been a tense one for a very long period of time.

If Mozart's piece was not bellicose enough in its musical spirit and expression, it was left to a pupil and friend of Mozart's, Freystädtler, to compose a piece with the title: Die Belagerung Belgrads, eine Historisch Türkische Fantasie, oder Sonata für das Clavier mit Begleitung einer Violin. This piece was published by Artaria in 1791, with the

6 Otto Erich Deutsch, Mozart, a Documentary Biography (Stanford, California, 1965), p. 309: »Mozart's interest in this war is attested by 'Ein deutsches Kriegslied' (K. 539) and another song, 'Beim Auszug in das Feld' (K. 552), as also by the country dance (K. 535), entitled 'La Bataille' or 'The Siege of Belgrade' (see 19 March 1788). " On p. 311 - for March 19, an announcement in the 'Wiener Zeitung' list new Mozart's works available at the Lausch's music establishment, among them - 'Die Belagerung Belgrads'!

7 Ibid., p. 364 and 365.

8 Ibid., p. 309. 1964, p. 606.

9 Köchel-Verzeichnis, 6th ed. (editors A. Weinmann and G. Sievers), 
plate number 280. According to RISM there are some 6 copies of this edition still attested though 2 of them seem to be incomplete. ${ }^{10}$

This composition belongs to the type of works, similar to the then fashionable 'battle-pieces' of which perhaps the most famous example is Kotzwara's 'Battle of Prague'. Fully descriptive the score of this piece contains titles above various segments of the composition depicting specific moments in the course of the obviously bloody encounter of the two adversary armies. The title-page contains besides the title a list of "Vorkommende Stellen" which reads: Türkische Musik im Lager. Die Mannschaft stehet unterm Gewehr - Gewöhnliches Geschreÿ und Heulen der Türken - Der Feldpater gibt den Segen - Trompetenschall, Zeichen zum Ausmarsch aus dem Lager - Marsch - Ein panisches Schrecken verbreitet sich vor den K. K. Heere. Todesangst überfüllt die Türken - Sie zittern - die Reittereÿ marchirt auf. Man hört in der Ferne den Grenadiermarsch, mit Trommeln und Pfeifen - Erstes Treffen. Ausfall der Türken - Canonade - Verwirrung - Die Türken werden zurückgetrieben - Sie fliehen - Halber Sieg - Man hört neue Regimenter anmarchiren - Zeichen zum Angriff - Die Vorstädte werden mit Sturm erobert - Angst und Geschreÿ der Verwundeten Handgemenge - Niederlage der Türken - Man umkränzet des Siegers Haare mit Lorbeern - Der Bassa übergibt dem Sieger die Vestung - Zeichen der Trommel zum Abmarsch - Abzug der Osmanen ohne Waffen - Marsch der Oesterreichischen Truppen - Es herschet Ruhe und Freude - Es lebe Joseph der IIte - Es lebe Laudon der Sieger.

This lengthy description of individual segment of this composition serves as a 'table of contents' and in examining the piano part one can follow these indications although here and there one finds slight deviations in wording from that on the title-page. Perhaps the only more significant difference in the piano part is the appearance of a "Grosse Kanonade" after the segment indicating the conquest of the suburbs and the inverted order of praises for Joseph II and Laudon. In the violin part there are fewer text indications for segments than in the piano part since the violin has rests in several segments where the piano plays alone. But to compensate for this, the violin part, after the arrival of the cavalry has a segment with the title "Ausfall der Türken aus der Festung" which is missing in other listings. After the "conquest of suburbs" the violin part has an indication "General Sturm" that seems to coincide with the "Grosse Canonade" of the piano part. And after the crowning of victors with laurel wreaths the text is

10 Cf. MGG 4 (1955), cols. 935-936; also date corrections in MGG 16 (1979), 362. He is not listed in The New Grove! For still extant copes, see RISM A/I/3 - Einzeldrücke vor 1800, vol. 3 (1977), p. 116, \# F 1888. I am indebted to my colleague Professor Eva Badura-Škoda for obtaining a xerox copy of the work in the Vienna National library and sending it to me for study. To Professor Bojan Bujić I am indebted for the information about an un-recorded copy (not yet in RISM!) in the Politeo collection in Stari Grad in Yugoslavia; cf. also Arti musices 10/2, p. 184. 
more specific about the departure of the Turks: 'Marsch der Osmannen - so wie sie sich immer weiter entfernen, wird der Marsch immer stiller.' This indication is paraphrased once more a few bars later in the piece.

The composition is obviously amusing to modern ears as it contains some rather naive musical presentations of the story-telling nature. Perhaps the most amusing aspect of the piece is that the opening bars depicting "Türkische Musik im Lager" and "Die Mannschaft stehet unterm Gewehr" are reintroduced unchanged after the end of the battle with the title: "Es herschet Ruhe und Freude"! There are no real orientalisms in either melodies or harmonies, all sounds pretty much Viennese.

The most interesting and at the same time most disappointing example of a composition depicting the war-time activities of that period is the opera The Siege of Belgrade by the British composer Stephen Storace, ${ }^{11}$ produced at the Drury Lane Theater in London on January 1, 1791. This is not an unknown work in the history of the English opera and there is already a sizable number of references to it in the current literature on the opera in London and on Storace himself. It is a wellknown fact that this opera is based on Martin y Soler's "Una cosa rara", borrowing substantial aspects of the libretto and Storace openly acknowledged the borrowing of a number of musical numbers adapted for his own opera. ${ }^{12}$

The interresting aspects of this work will be discussed briefly here, yet the disappointing aspect of this work, at least for Yugoslav readers, consists in using Belgrade as a 'name in the news' to create an artificial feeling of reference to a more or less contemporary event. In fact, the plot of the opera could have been placed in any other geographical locale as well and has really nothing to do with specifically Serbian aspect of Belgrade. To start with, Soler's opera Una cosa rara, utilizing a libretto by the famous Lorenzo Da Ponte, ${ }^{13}$ presumably takes place in Spain and some of the characters in it have names that to this writer do not necessarily sound Spanish, a point which makes no difference for the $18^{\text {th }}$. century writer, composer or members of the

11 See pertinent entries about Storace in standard encyclopedias. See also: A. Loewenberg, Annals of Opera, $3^{\text {rd }}$ edition (1978), cols. 485-6. RISM A/I/8, i.e.. vol. 8 (1980), p. 279, lists 37 copies of the score in existence. Sonneck, op. cit., II, p. 1003, lists 2 copies of the libretto in the Library of Congress as well as copies of the text (?) of »Songs, duets, trios, choruses etc. in The Siege of Belgrade«, apparently a posthumous edition since it is stated: "Music by the late Mr. Storace«!

12 An examination of the score demonstrates that each piece has a listing of the composer; though Martin y Soler is referred to as 'Martini' the title of 'Una cosa rara' is not mentioned anywhere. For basic data about Martin y Soler see standard reference encylopedias, the most recent full listing in The New Grove, 11, pp. 735-736.

${ }_{13}$ Most recently The New Grove, 5, pp. 236-238. 
audiences attending the performances of operas. The plot of the opera is somewhat silly, containing various devices that were more or less typical for a standard $18^{\text {th }}$ c. opera; the element of unrequited love and problems preventing true lovers to get together are ubiquitous in opera. The wearing of masks and mistaken identities are another set of points that make for a good show bringing comic misunderstandings to the fore. Una cosa rara was produced in Vienna on November 17, 1786. It contained several quite attractive and popular musical numbers. The concluding theme in the Finale of the first act was quoted by Mozart in the banquet scene in the opera Don Giovanni, testifying to its excellence as well as widespread knowledge of the melody. By 1789 Martin y Soler's opera reached London and became quite well-known there as well. ${ }^{14}$

When examining Storace's life and creativity in connection with the opera The Siege of Belgrade there are several rather interesting if not outright curious coincidences. To start with, Storace lived in Vienna from about 1784 to 1787 , thus he may have been present at the first performance of the Una cosa rara. But, perhaps more importantly, Storace's younger sister Ann (better known as Nancy) was a well-known singer in Vienna in those years and she was the first Susanna in Mozart's Le Nozze di Figaro. ${ }^{15}$ In addition, the Irish tenor Michael Kelly was the first Don Curzio and Don Basilio. ${ }^{16}$ The Storaces and Kelly together with another Englishman, Attwood (a pupil of Mozart's), left Vienna together in February 1787 on their way back to London where their carreers were to remain intertwined and in a more or less steady contact.17 Furthermore, there is great likelihood that at some point during his stay in Vienna, Stephen Storace may have met Salieri, the official 'court-composer' in that period. And whatever Kelly's reliability may be in his memoirs, he does mention an evening at Storace's where a quartet was performed (played by Haydn and Dittersdorf on the violins, Mozart on the viola and Vanhall on the cello!) and adds that Paisiello was in the audience. ${ }^{18}$ In short Storace was per-

14 First performance in London on January 10, 1789. For reactions of the press and related events, see Fred Petty, Italian Opera in London, 1760-1800 (Yale University Dissertation, 1971), pp. 305-307. (University Microfilms ed. 1975). The very same finale melody used by Mozart as a quotation from 'Una cosa rara' was used by Storace in the finale of Act I of The Siege of Belgrade.

15 For biographical information see The New Grove, 18, p. 182; MGG $12,1412-1413$.

${ }_{16}$ Cf. The New Grove, 9, p. 855; MGG 7, 824-825.

17 Deutsch, op. cit., p. 286: "In the evening of 26 February Attwood, Kelly, Ann Storace and her mother and brother reached Salzburg from Vienna on their homeward journey to London. During the morning of the $27^{\text {th }}$ they were shown the town by Leopold Mozart...«

18 Reminiscences of Michael Kelly of the King's Theatre and Theatre Royal Drury Lane, vol. I (Reprint 1968), p. 237-238. Incidentally, Kelly sang in the first English performance of 'Una cosa rara' in 1789. 
sonally acquainted with all the composers from whose works he was to make borrowings and use their melodies in pasticcio-like works of his while in London. The direct quotations from the works of these composers should not be viewed as 'plagiarisms' but rather as expressions of esteem and honor in which Storace held them; and a glance at the scores reveals that almost everyone of these borrowings is openly acknowledged by listing the actual composer's name. In the case of Martin y Soler (who is usually referred to as 'Martini') it is known that he was in London in 1795 at a time when Storace's opera was being performed and there is, to this writer's knowledge, no recorded protest regarding the possible dis-pleasure of Soler's for the use of his tunes in Storace's work. ${ }^{19}$

For the opera The Siege of Belgrade, the libretist was James Cobb of whom is relatively little known. ${ }^{20}$ All that is presently known about this particular opera is based on the text of the libretto and the published piano-vocal score containing favorite tunes. All orchestral parts and scores for his London operas Storace was unfortunate enough to lose in the fires at various theaters in the early part of the $19^{\text {th }}$ century. ${ }^{21}$ While the piano reduction does occasionally contain indications for other instruments, the number of these remarks is insufficient for an attempt at restoration of a full score as it was used for original performances. It can be said, however, that as far as is presently known, with one single exception Storace composed his operas as "Singspiels" or 'plays with music' leaving the dialog in its spoken form, without recitatives. ${ }^{22}$

The plot of the opera, as indicated earlier, has nothing to do with Serbs, but with Turks and Austrians and the characters alleged to be Serbs, presented as at times loyal subjects of the Turks or as grudging and longing for protection by the Austrians, are essentially the depictions of what the nobility thought peasants may be like. The Turkish 'cadi' Useph is listed in the list of characters as 'Justice of the peace' - a concept far removed from what in actuality it may have been. Obviously we have here an anglicized version of a Viennese libretto based on a Spanish play. The Austrians are represented by Colonel Cohenberg and his wife Catherine. The Turks are The Seraskier, the

19 About Soler's being in London, see The New Grove, 11, p. 736, between his two stays in Russia.

20 Cf. Dictionary of National Biography, under the name. Cobb lived from 1756 until 1818 and worked in the East India Company while writing on the side.

21 The New Grove, 18, 181; within the last quarter century Roger Fiske has studied and published more studies about Storace than anyone else. See also Fiske's English Theatre Music in the Eighteenth Century (London, 1973), pp. 487-539 a lengthy chapter on Storace and his músic and some discussion of The Siege of Belgrade, which, according to Fiske »had its premiere on the night Haydn first set foot in London«! Carthage.

${ }^{22}$ The only opera with sung recitatives by Storace was Dido, Queen of 
commander of Turkish forces, and Useph, the Justice of the Peace. Among other leading characters are Leopold - a Serbian 'villager'! - who is in love with Lilla, sister of Peter. Peter wishes, however, that his sister marry Useph. Peter also is in love, he loves Ghita. There are three more characters, two presumed to be Serbian villagers named Anselm and Michael; and Ismael who is a close confidant of Seraskier and of Useph.

It may be pointed out that in Una cosa rara the two leading females are also named Lilla and Ghita and they are taken over in their situations almost unchanged into Storace's opera. Their respective lovers in Da Ponte's libreto are Lubino (for Leopold) and Tita (for Peter). Some other roles are in a slightly different relationship. The remaining female character of significance in Una cosa rara is the Queen (Regina). The counterpart for the role of Seraskier is Queen's son, the Prince (Principe). In some aspect Ismael approaches the role of Corrado, but rather slightly. A few scenes with their devices have been taken over completely into The Siege of Belgrade. The opening with a chorus followed by Lilla's aria imploring for help is one such example. ${ }^{23}$ Another is the quarreling of Tita and Ghita which becomes the quarrel between Peter and Ghita; ${ }^{24}$ or still another good example is the sextet scene starting with Lilla and Ghita seeing masked men, they assume these are their husbands while in fact Principe and Corrado (or Seraskier and Ismael) are approaching them to be interrupted by the girls' husbands. ${ }^{25}$

A comparative study of the 2 libretti is a good example of adaptation of the text, not always as skillfully done as by the original writer. And in case of musical borrowings, again adjustments are provided and in most cases Storace abbreviated the example from which he was borrowing, making it much shorter and more to the point.

23 In Da Ponte's libretto of 'Una cosa rara' the first act begins with a chorus of hunters and huntresses (!) singing a prayer to the goddes of the woods. The next musical number is a trio in which Queen's son - Principe - wonders why his mother exposed herself to danger while hunting. The third singer is Corrado, a confidant of the Prince. Then only Lilla arrives imploring the Queen to help her since Lilla's brother wants her to marry the 'odious justice'. In Cobb's libretto of 'The Siege of Belgrade' the first act begins with the chorus of Turks, followed by Lilla's entry who sings "Lost, distressed I'm thus driven from home" revealing afterwards in the Trio sung by Seraskier, Lilla and Ismael, that her brother wants her to marry the ugly Useph, »Justice of the Peace in our village». The music for Lilla's arias in both instances is the same except for a transposition from $\mathrm{F}$ minor (in 'Cosa rara') to G minor (in 'The Siege').

24 Number 6 in 'Cosa rara' and number 5 in 'The Siege' where it is indicated that the music is by "Martini', in both instances in the same key of F major.

25 Act II, scene 7 (number 22 in the score) of 'Cosa rara' and number 5 of act II in 'The Siege'. In both cases in the same key of G major and in both instances Lilla and Githa begin the opening segment of the sextet. 
It is also interesting to note that Una cosa rara is in TWO acts while The Siege of Belgrade is in THREE acts. The total of musical numbers in Una cosa rara amounts to 30 (14 in the first act and 16 in the second act). In Storace's opera, though in 3 acts, the total amounts to 29 musical numbers. ${ }^{26}$

A brief summary of the musical aspects of Storace's opera reveals that the Overture, in large part composed by Storace, ${ }^{27}$ contains in its third segment (being in 'fast-slow-fast' pattern) a direct quotation of Mozart's well-known 'rondo alla turca' (K. 331) which, as the curtain goes up continues as the chorus of the Turkish soldiers. All of this, by the way, utilizes the segment of Mozart's work in the major key (here transposed to D major). Thereupon follows a dance of Turkish soldiers (opening part in minor!) and a dance of Turkish women (back to Major) and the concluding stanza of the chorus of Turks. ${ }^{28}$ Storace did not cite Mozart's name presumably because this may have been a well-known work which did not need introduction to its listeners. Of the remaining 10 numbers in Act I, Storace composed only four while six are directly taken over from Martin y Soler's Una cosa rara. Number 2 in Storace's opera - Lilla's plea for help is the equivalent of number 3 in Una cosa rara (again Lilla's plea for help, from the Queen!). The following, number 3 in Storace's opera is a paraphrase of the trio number 2 in Una cosa rara (the two male equivalents, Principe and Corrado are remade into Seraskier and Ismael, while the role of Queen is totally recast to fit the new situation including Lilla as the third character in this piece). An attractive tune, set as Seraskier's aria with the text "The rose and the lilly", number 4 in Storace's opera is taken over from Una cosa rara, where it appears as number 5 and is sung by the Prince with the text "Piu bianca di giglio". The next duet of Ghita and Peter (number 5 in Siege), beginning with the words: "How the deuce I came to like you, I am sure I cannot tell ", is identical to the duet of Ghita and Tita (number 6 in Soler's opera) with the opening text: "Un bricone senza core, no, non voglio piu sposar". The 3 following numbers $(\# 6=$ Ghita's aria, \#7= trio for Useph, Peter and Leopold, and \#8= Anselm's aria) are all by Storace. However, number 9 Lilla's aria "Blithe as the hours of May" is an adaptation of an aria for Lilla in Una cosa rara, where it appears as number 13, "Dolce mi parve un di". The following trio for Seraskier, Lilla and Ghita is by Storace, and the finale of Act I of The Siege utilizes the concluding theme from the finale of the first act of Una cosa rara - the same theme that Mozart quoted in Don Giovanni.

26 Excluding the Overture, Storace's opera has eleven numbers in the first act, ten numbers in the second act and eight in the third act. Each act has an ensemble for the finale, in the Italian style.

27 Storace definitely is the author of the opening fast section, and perhaps of the slow section as well.

$28 \mathrm{Cf}$. the Appendix. 
In the second act of The Siege of Belgrade, of the total of ten musical numbers, four are borrowed: \#3 is by Paisiello (so far remains unidentified); \#5 sextet is from Una cosa rara where it is number 22 (or \#8 in Act II); \#7 is by Salieri consisting of a minuet-like tune and an alla breve segment in alternation. And \#8 is attributed to Kelly, being a short melody which in the action of the play, Seraskier is singing from outside serenading Lilla (as a direct paraphrase of a similar situation in Una Cosa rara!). As for the concluding third act, its seven opening numbers are all by Storace, and the finale begins with a Storace tune and procedes with Martin y Soler's tune from the finale of Act II of Una cosa rara where it plays a relatively less important role, starting at bar 223 of that Finale. In Storace's opera, however, that melody becomes the dominant one for the concluding Allegretto in $3 / 8$, bringing the whole opera to its close. All told, about one third of the whole opera contains borrowed music while Storace composed the remaining two-thirds.

A thorough look at the libretto, however, indicates that there are additional segments of the play in which some kind of music is required, more specifically in the fighting scenes which on the basis of description as to what is to take place might require a substantial number of minutes during which, according to the libretto, the drums and trumpets are to play. ${ }^{29}$ Whether these florishes were improvised or composed remains unknown at present. Undoubtedly they contained some conventional sounds associated with the battles.

As might be observed the selection of names for characters hardly allows to view this work as dealing with a "Serbian" situation or persons in spite of the libretto's indication that when the curtain rises one can see: "Village of Servia, with the Danube; on one side the Turkish Camp, on the other the Austrian, which appears at a distance..."? Even the opening chorus is by Turkish soldiers and the dance is by "Turkish peasants of both sexes" as named in the libretto.

There is, however, one point which arouses some curiosity with respect to Belgrade in this whole story. Namely, the piano-vocal score

${ }^{29}$ Nowhere is this more prominent than in the concluding scene for which the libretto has the following lengthy description:

»Castle and view of Belgrade - the siege commences. Guns firing balls of fire, supposed to be thrown to fire the citadel. A party of Turks are repulsed by a party of Austrians. An Austrian soldier fights some time sword in hand with a Turkish soldier; but losing his sword, takes a pistol from his belt and fires at him; the Turk falls and is thrown into a ditch that surrounds the castle - Enter the Seraskier and Cohenberg fighting. The Seraskier falls - Peter, Leopold, etc. fight with the Turkish soldiers. Useph enters and flourishes his sword on the side of the Turks; but finding they are sure to be conquered joins the Austrians. Drums and Trumpets heard all the time."

Neither the score nor the libreto contain any further directions nor musical accompaniment for this scene which must have been fascinating to watch. 
was published in London in 1791 and according to the title page, ${ }^{30}$ the inscription on the bottom-part reads: London, Printed and sold by J. Dale, No. 19 Cornhill, \& No. 133 Oxford Street, opposite Hanover Square.

Above that line, just beneath the representations of tents on the right hand side of the picture in small letters it is recorded: Entered at Stationer's Hall (which suggests that the work was copyrighted?).

Yet beneath the center part of the publisher's name and address in very small letters is written: Neele sculpt 352 Strand. This seems to be the name of the engraver with his address in London. It might be worthwhile for an art historian to pursue the point where Neele (if that is his name?) obtained the information and illustration to serve him as a model for his drawing for this title-page, which is most interesting, indeed. While it is by no means an 'authentic' representation of the view of Belgrade and the fortress, it is nevertheless rather close in its appearance to the actual view that Belgrade does offer from the distance from the nearby town of Zemun. Quite a few points about the fortress are not only idealized and incorrect, but the question remains which one of the number of engravings of Belgrade may have served as a starting point for the engraver. It is for art historians now a task to determine this lineage on the basis of a number of Central European drawings of preceding periods.

Storace's opera The Siege of Belgrade, in addition to its run in London, had a rather curious role in the musical life of the United States of America, where it was presented in New York on December 30,1796 . While it was not one of the more popular works, nevertheless, a number of arias from it were published in subsequent years well into the $19^{\text {th }}$ century, bringing the name of Belgrade into the consciousness of the musical audiences of the 'New World'. ${ }^{31}$

30 See the enclosed illustrations. On the basis of the piano-vocal score it is possible to reconstruct the cast of characters and the main actors who sang at the opening performances; thus of the three female singing roles Catherine (wife of the Austrian colonel Cohenberg) was played by Mrs. Crouch; Lilla - Nancy Storace; Githa - Mrs. Bland; and for male roles: Seraskier - Michael Kelly; Leopold - John Bannister, Jr.; Peter - Charles Dignum; Useph - Richard Suett, known as a great comic actor.

31 The documentation for the performances of Storace's opera The Siege of Belgrade is ample and plentiful. The easiest access begins with Joseph $\mathrm{N}$. Ireland's Records of the New York Stage from 1750 to 1860, 2 vols (New York 1866 - reprint 1966). In vol. I, p. 142, there is a record of a performance at the John Street Theater on December 30, 1796, which was the first time in America for this opera. The announcement states 'music by Storace, accompaniment by Pellesier'. That is Victor Pelissier, of whom relatively little is known at present; much more can be expected from the systematic researches about him, now in progress, by Elena Zimmerman. One of the well-known actors of the time named Jefferson, was listed as playing the role of Leopold and having painted 'new scenery' for the show. The 1799 performances at the New Park Theater in New York omit in their 
We might add, as a kind of a Coda, that the very same libretto by James Cobb seems to have remained of interest to at least one English composer, since in 1830 a composer, often listed as John Westmorland, actually John Fane Burghersh, the eleventh Earl of Westmorland (1784 -1859) composed an opera L'Assedio di Belgrado which appears to have been performed on April 15 of that year; furthermore, the same opera was presented in English, this time as Catherine, or the Austrian Captive by the Royal Academy of Music in London, in October of the same year 1830. At this time we have no knowledge of the whereabouts of the score of this work if it still merits any further consideration. ${ }^{32}$

listing 4 of the lesser roles; the 1807 season ended at the Park Theater with a performance of the same opera.

The last recorded performance of this opera in American took place in 1840 on December 21 and 22 at the Park Stage when John Braham came for a tour of the USA though it was for him an artistic farewell in his 67th year (On Braham and his connections with the Storaces, Stephen and Nancy, see The New Grove, 3, 154-155). See also George C. P. Odell, Annals of the New York Stage, I (New York, 1927), 428-434, for performances in 1796 and 1797; vol. II, pp. 20, 469, 500 and 523 for stagings in 1798, 1817 and 1818; vol. III pp. 13, 64, $99,140,235,240,304,318,388,516,550,568$ and 570 for performances between 1821 and 1831. Loewenberg, loc. cit., mentions performances in Philadelphia in 1801 and 1840; hitherto unnoticed is the performance in New Orleans, listed in Nelle Smither's A History of the English Theatre in New Orleans (1944), p. 247, recording that on March 14, 1834, at the American or Camp Street Theater there was the single performance of this opera in that city. She lists the names of 5 actors in some of the leading roles, reducing the plot to the bare bone.

In his A Bibliography of Early Secular American Music (revised ed. by W. T. Upton), Sonneck lists on p. 381 the following:

»The Siege of Belgrade, opera, was to be performed for the first time in New York as a comic opera in 3 acts, accompanyments by Pelisier, on December $30,1796$.

The Siege of Belgrade, a sonata for the pianoforte, advertised in January 1797 as 'just published by G. Gilfert, at this Musical Magazine, No. 177, Broadway, New York.«

This listing raises a small problem as it does not appear in American Music Bibliography 1698-1800, by Priscilla S. Heard (Waco, Texas, 1975). In this latter book, however, there is a listing on p. 208, under \# 47692 of the following: "Schröter, Johann Samuel, The conquest of Belgrade, A Sonata for the Harpsichord or Pianoforte... New York, Printed for G. Gilfert \& Co. (1795). « For information about Schröter see MGG, 12 (1965), cols. 88-90 and The New Grove, 16, 746-747. Ronald Kidd (the author of the latter entry) considers it doubtful that Schröter is the author of the work that went under that name. No copy was available for examination at the time of this writing.

32 Cf. The New Grove, 3, pp. 463-464, article by Nicholas Temperley; the bibliography lists a review of the performance of the opera Catherine to have been published in Harmonicon, viii (1830), $525=$ inaccessible to this writer! Fétis, in his Biographie universelle..., lists in vol. $8(1875)^{2}$ on pp. 457-458 more data about this composer. On the basis of the Italian title and the fact that Burghersh was consul in Italy, in Florence until 1833, perhaps one may surmise that the first performance of his opera in April did take place in Florence, whereas the October staging did take place at the Hay- 
And as a concluding chord, at least as far as we know at present, one may mention Constantin Julius Becker's opera Die Erstürmung von Belgrad staged in Leipzig on May 21, 1848. We know of no reports of its performance ${ }^{33}$ except that the name of Belgrade provided once more sufficient attraction for still another composition, just at the time when Serbian artistic music was about to start its own historical development.

\section{APPENDIX}

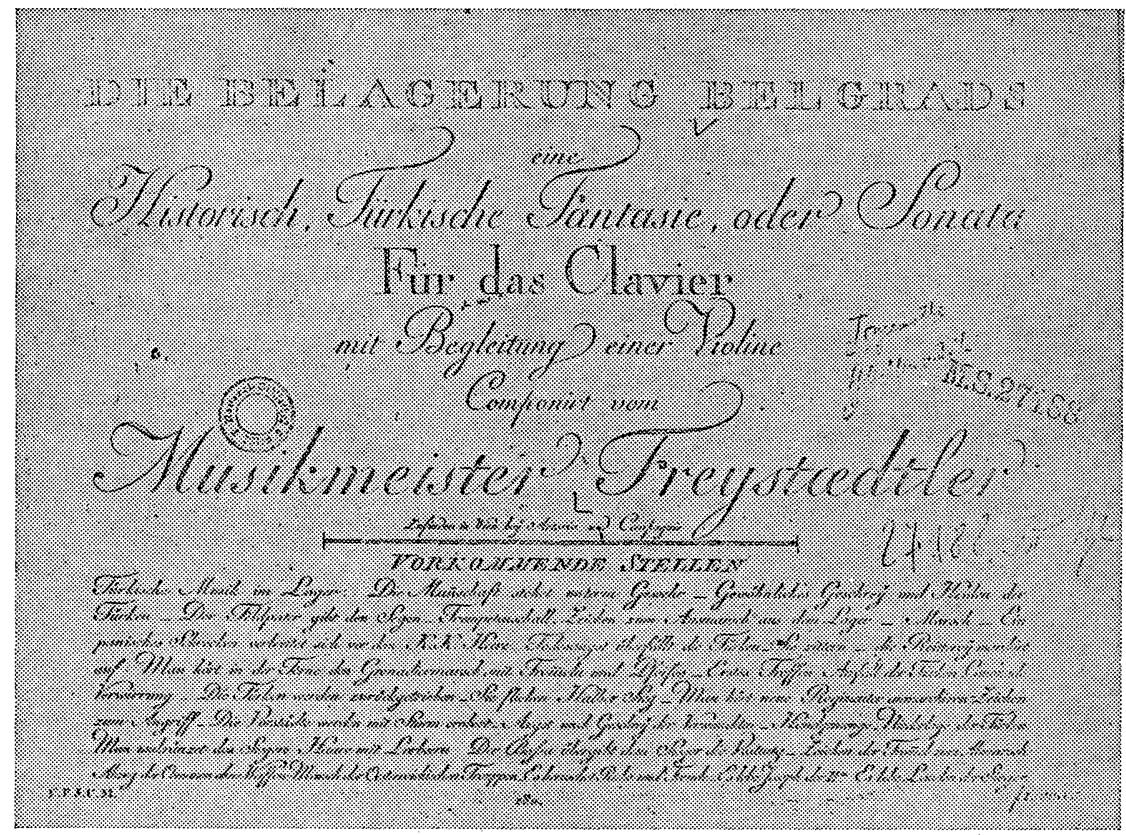

Title page of Freystädtler's composition Die Belagerung Belgrads

market theater by the students of the Royal Academy of Music in London, of which he was the president at that time. The vocal score was, according to Fétis, published by Cramer and Beale.

${ }_{33}$ For Becker see MGG, 15 (1973), cols. 597-598; also The New Grove, 2, p. 337. The spelling "Entstürmung « in The New Grove is certainly a misprint.

P. S. After having worked with the microfilms of the copies of documents in the Library of Congress, we are just learning that the piano-vocal score of Storace's opera has been reprinted in the Kalmus Vocal Series, as \# 9064, published by Belwin Mills Publ. Corp. in the USA, with no indication of date of publication. 
The SIEGE OF BELGRADE, music by Stephen Storace and from other composers' works

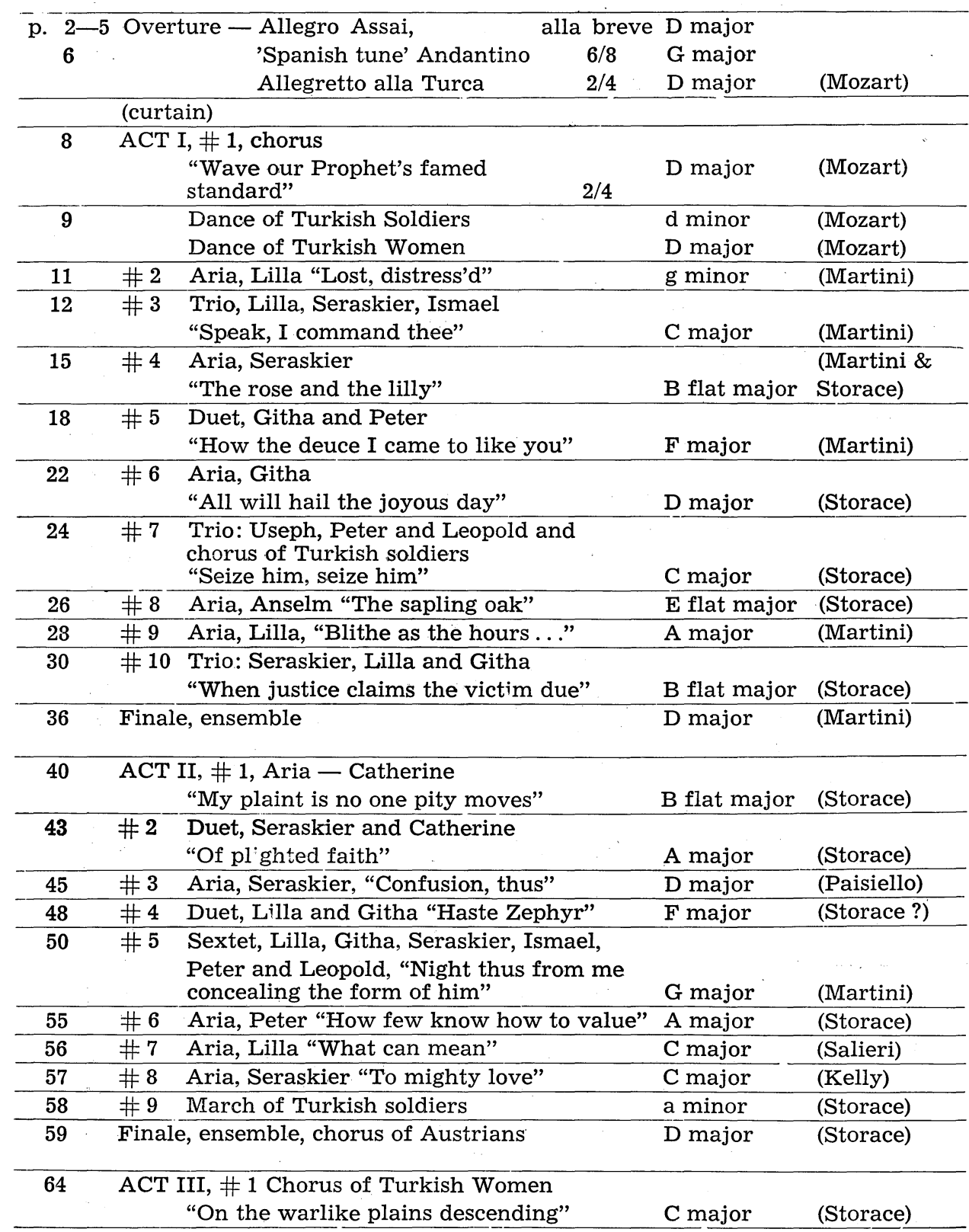




\begin{tabular}{cclll}
\hline 65 & $\# 2$ & $\begin{array}{l}\text { Aria, Catherine } \\
\text { "No more I'll heave the tender sigh" }\end{array}$ & F major & (Storace) \\
\hline 67 & $\# 3$ & $\begin{array}{l}\text { Aria, Leopold } \\
\text { "How provoking your doubts" }\end{array}$ & E major & (Storace) \\
\hline 68 & $\# 4$ & $\begin{array}{l}\text { Aria, Lilla "Domestic peace" } \\
\text { "Sometime ago I married a wife" }\end{array}$ & E flat major & (Storace) \\
\hline 72 & $\# 5$ & $\begin{array}{l}\text { Aria, Yuseph } \\
\text { "Somajor }\end{array}$ & (Storace ?) \\
\hline 73 & $\# 6$ & $\begin{array}{l}\text { Duet, Lilla and Leopold } \\
\text { "Thuugh you think by this to vex me" }\end{array}$ & F major & (Storace) \\
\hline 75 & $\# 7$ & $\begin{array}{l}\text { Aria, Seraskier } \\
\text { "Love and honour now conspire" }\end{array}$ & E flat major & (Storace) \\
\hline 78 & Finale, ensemble & $\begin{array}{l}\text { (Storace } \\
\text { and Martini) }\end{array}$ \\
\hline
\end{tabular}

NB We are indicating with a question mark after the name of Storace those pieces for which no author's name appears in the score although the likelihood is that Storace did write those segments.

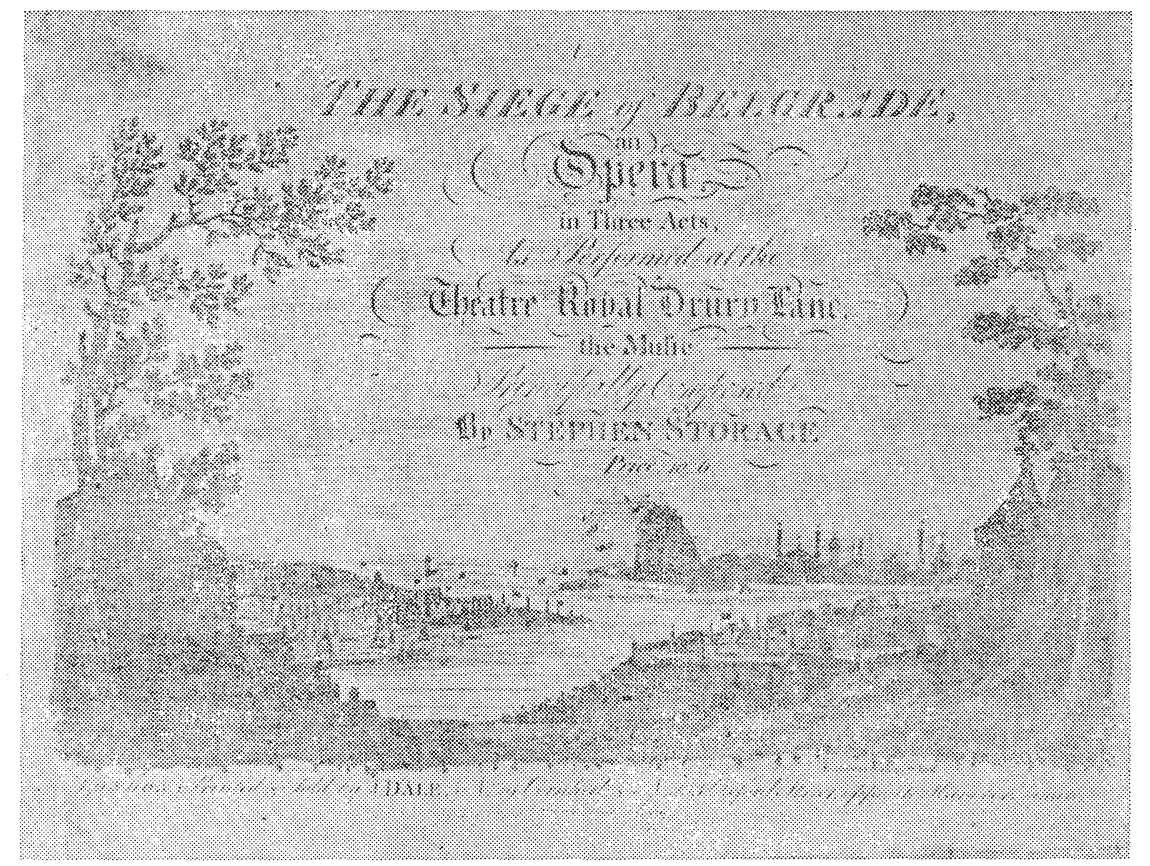

Title page of the piano-vocal Score of Storace's opera The Siege of Belgrade 


\section{STEGE OF BILGRADL.}

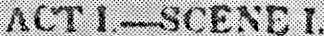

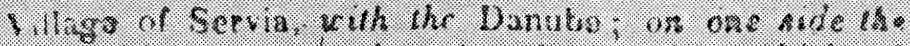

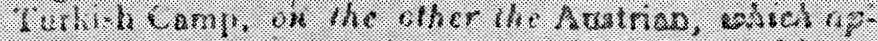

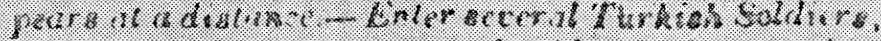

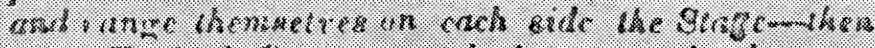

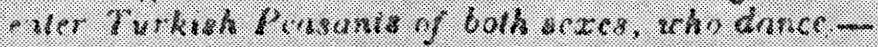

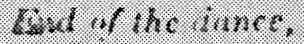

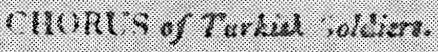

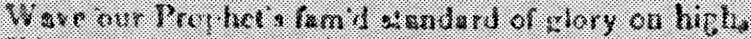

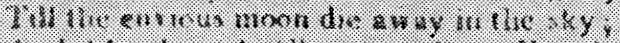

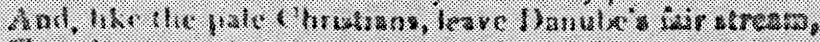

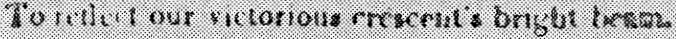

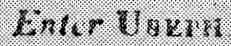

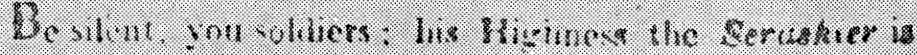

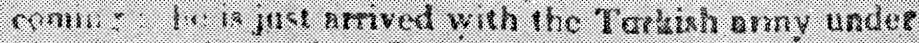

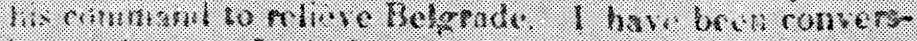

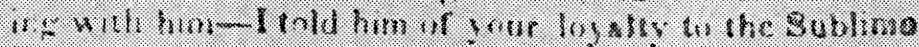

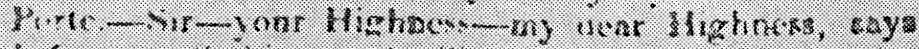

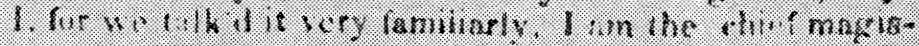

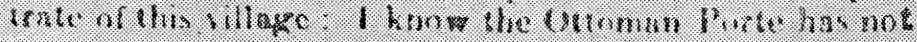

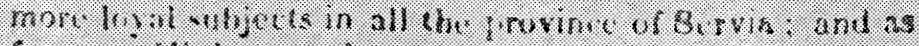

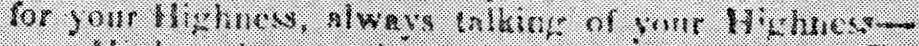

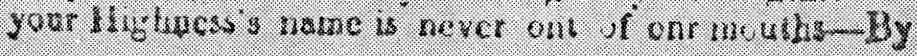

The Siege of Belgrade - libretto, first page of text 


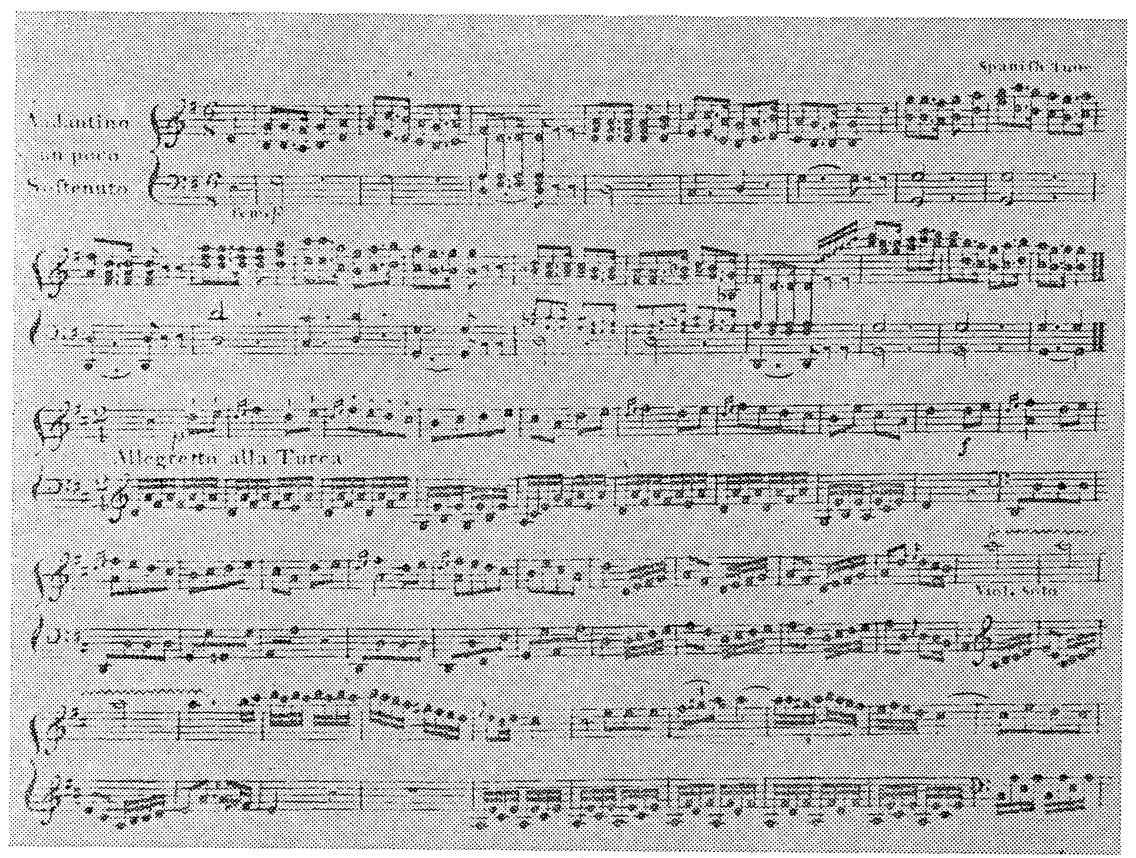

The Siege of Belgrade - Overture, middle - slow — part as "Spanish Tune« followed by the concluding fast part - from Mozart's Rondo alla turca

\section{POVZETEK}

V zadnjih desetletjih 18. stoletja je bil Beograd večkrat kraj dogajanja zgodbe, ki jo slikajo glasbene kompozicije. Prvi podatek datira iz leta 1784; gre za balet »L'assedio di Belgrado«, o katerega glasbi ničesar ne vemo. Obleganje, ki je tu prikazano, je bilo leta 1456 , ko so Turke napadli Madžari. Medtem ko so bile borbe za Beograd nasploh pogoste, so skladatelji prav v letih od 1789 do 1791, to je v času avstrijske dominacije in vojne s Turčijo večkrat uporabili Beograd $v$ naslovih svojih kompozicij. Celo Mozart je menda najavil eno od svojih del (K. 535) kot »La Bataille« ali »Obleganje Beograda«.

Precej zabaven je Freystädtler s svojo kompozicijo »Die Belagerung Belgrads« za klavir in violino iz približno leta 1790/91. V stilu tedaj tipičnih »bojnih kompozicij« opisuje ta obleganje in bitke avstrijskih in turških armad ter se končuje $\mathrm{s}$ hvalospevom avstrijskemu poveljniku Laudonu in cesarju Jožefu. Druga zanimivost je opera »The Siege of Belgrade« Stephana Storacea, ki so jo uprizorili $\mathrm{v}$ Londonu 1. januarja 1791. Njen libreto temelji na libretu opere »Una cosa rara" skladatelja Martina y Solera, katere dejanje se odvija $v$ Śpaniji. Tudi zgodba je podobna in celo imena oseb so doslovno prevzeta iz ene opere $v$ drugo. Opera »The siege of Belgrade« je pravzaprav pasticcio in vsebuje glasbo Solera, Mozarta (rondo alla turca!), Salierija in Paisiella. V zgodbi ni ničesar specifično srbskega, kajti tu je uporabljen kraj Beograd le kot sodobno »ime v novicah « in ozadje 
za dejanje. Vendar je zanimiva naslovna stran tega dela, saj kaže dokajšnjo podobnost $\mathrm{s}$ splošnim videzom mesta Beograda. Storacejeva opera je bila nekoč priljubljena v Ameriki vse od prve uprizoritve v New Yorku leta $1796 \mathrm{pa}$ do zadnje leta 1840 . Ista zgodba je inspirirala za opero leta 1830 še nekega drugega angleškega skladatelja, medtem ko je Nemec C. J. Becker napisal opero, ki ima v naslovu Beograd, še leta 1843. Takrat pa se že začenja samostojen razvoj srbske glasbe in poslej se ne pojavijo več nikakršna glasbena dela tujih skladateljev $\mathrm{z}$ omenjeno tematiko. 